\title{
People's Lawyers, People's Justice and Neoliberal Globalization
}

\author{
By Gill H. Boehringer*
}

This paper examines the growth of legal and non-legal activism in the struggle for social justice in the era of globalization. There are a number of different approaches described, including the use of formal law supported by mass action on the streets, the establishment of alternative justice systems outside the legal systems of the state, and People's Tribunals which are an increasingly important part of the resistance to the negative impacts of globalization on contemporary societies. People's struggles in Brazil, Mexico, the Philippines and Turkish Kurdistan are discussed.

Keywords: alternative justice systems, globalization, legal strategies, people's justice, people's lawyers

\section{Introduction}

These are perilous times, lawyers, legal academics and law workers will face increasing threats to people's rights and justice from the state-corporate alliance that has strengthened greatly in the past several decades and posed serious challenges to social justice following the Global Financial Crisis (OECD 2014, WSWS 2014, Ross and Trachte 1990, Boehringer 2011). They must consider how to respond. It is important that they also ask: how the people have responded? Lawyers do not have all the answers, and there is much more to be learned from the experience of the people.

In the recent years there have been important developments which look outside the traditional courts and practice of law, even beyond the people's lawyering of the kind that the Filipino congressman and human rights lawyer, Neri Colmenares, spoke about recently. He made word of the "legal counter-offensive" strategy that is based on the experience of the impressive Philippine National Union of the People's Lawyers. (Colmenares 2013). In this paper, I will reflect on the spectrum of strategies that are used by lawyers and people to resist the repression and exploitation which have been super-heated by the neoliberal hegemony which is at the core of contemporary globalization (Garth and Sarat 1998). In particular I focus on bottom up strategies arising out of the needs of the masses in the specific circumstances of their repression and exploitation.

${ }^{*}$ Honorary Associate, School of Law, Macquarie University, Australia. 


\section{Resistance to Neoliberal Globalization}

The contemporary world, dominated by the neoliberal policies and practices associated with "free market" globalization, has seen the imposition of terrible conditions upon hundreds of millions of people around the globe (Lechner and Boli 2012, GRAIN 2012). Repression and exploitation are never simply imposed. They arise out of historically prepared conditions and under the specific social circumstances of the time. How these are realized depends on the existing array of social forces and the dynamic which develops between them. Of course in our era, the forces of wealth and power associated with the corporate capital which exercises significant control over the state are dominant (Tubbs 2013, Bakan 2004). The people are being trampled upon, but the people will always resist sooner or later, and today, across the globe, we see that resistance in many forms. And when the people resist, there will always be lawyers who stand with them (Sarat and Scheingold 2005, Ginger 1972).

Over the past fifteen years there has been an upsurge of radical critique of law, legal institutions, the practice of law as the impact of globalization and the "war on terror", things which are felt around the globe (Nayar 2001, 2003, 2006). That impact includes increased state surveillance and repression, "austerity" policies, and human rights abuse, often in circumstances of impunity (Sands 2006). At the same time, corporate power has been unleashed so that the conditions for working class and even middle class people have seriously deteriorated, inequality has grown significantly, and the threat to the environment has become an existential crisis (Oxfam Report 2014, Global Witness 2014).

Progressive lawyers have formed organizations for the specific practice of law in the interests of the people. These organizations that take different forms, have differing ideologies but similar strategies such as the People's Law Office in Istanbul with its pronounced revolutionary socialist perspective and collective living and work (Boehringer 2014c) and the militant Philippine National Union of People's Lawyers, associated with the National Democratic Front (Boehringer 2009). Essentially the Turkish and Filipino lawyers have similar strategies: both have diverse and close links with civil society groups, trade unions and social movements to challenge state repression and corporate exploitation. In response, such lawyering makes them the subjects of state legal harassment (often imprisonment on unjustifiable charges) and, in a number of countries including Turkey and the Philippines, assassinations by military and paramilitary groups.

Left critiques of law have once again been delivered after some years of relative silence after the largely Marxist influenced work of the late 1960s up to the early 1980s was superseded by postmodern 
theorizing as was the case in other disciplines. The current Marxist and progressive theorizing, significantly, includes a challenge to traditional understandings of international law. Much of this work comes from the scholars associated with Third World Approaches to International Law (TWAIL). (See the electronic journal of Law, Social Justice, and Global Development online: http://bit.ly/1W4w4yI).

A development of particular interest to people's lawyers is the increasing use of People's Tribunals, linked to campaigns for social justice and the exposure and prevention of injustice (Klinghoffer and Klinghoffer 2002, Byrnes and Simm 2013, Byrnes 2012). They have dealt with a wide variety of issues, but they are all concerned with the violations of civil liberties, human rights and abuses of the environment by states and, increasingly, by corporations. Such tribunals are a reflection of the contemporary withdrawal of faith in the willingness of states and corporations to act to protect humans, other creatures and the environment according to acceptable standards of law and morality (Nayar 2001, 2003, 2006, 2007). I recommend the development of people's tribunals at the local community level to provide continuous monitoring and judgment of the state and corporate abuses of the people and their environment (Boehringer 2014c, 2014d).

\section{Rejectionist Projects}

In some parts of the world, there has been a more pronounced, physical withdrawal from the state: the establishment of autonomous areas, or what might be called liberated zones. Twenty years ago we were virtual witnesses to the Zapatista rebellion in Chiapis, Mexico. It was, and still is, an inspirational phenomenal (Esteva and Prakash 1998, Hayden 2002, Womack 1999).

\section{North Kurdistan}

In North Kurdistan (eastern Turkey), the majority of the Kurdish population has embarked on an "Autonomy Project" (Democratic Society Party 2008) which is a decentralized "confederal democracy" outside the jurisdictional power of the Turkish state, which has treated them as second class citizens (Kowarsch 2013). A major element in this project is an alternative justice system which takes the place of the state legal system for resolving conflicts, settling disputes and dealing with the unacceptable behavior of individuals. Their achievement in instituting an alternative justice system is a result of the inability of the Turkish state to impose a military solution due to the strength of the guerrilla army of the Kurdish Workers' Party (PKK) and the determined resistance of the people in the face of the extraordinary 
atrocities that happen against the civilian population in that region, including the razing of 5000 villages.

In the Kurdish project there are basic principles such as anti-state; anti-hierarchy; anti-professional and bottom-up. Thus, while they may need lawyers to defend them, the state should try to stop this development, and as advisors (they have established a think tank, a Legal Commission), it seems they do not wish to involve lawyers directly and as professionals, in what they refuse to call a legal system, they prefer to seek justice by non-adversarial, or non-litigious proceedings (Boehringer 2013b).

As in customary societies generally, Kurd's justice system emphasizes in resolving conflicts, disputes and anti-community behavior through discussion and negotiation, restoring peace in the community and moving forward with their neighbors. Sanctions are applied according to the circumstances and the wishes/needs of the families involved, as a part of the process of reconciliation. Compensation of some kind is normally a part of the settlement. However, in cases such as murder, there may be serious punishment, including a long term sentence in the mountain prison of the PKK. Yet this is subject to review and forms of parole may be invoked, usually involving community service.

The matters of complaint are brought before a panel of respected members of the community who facilitate the settlement, and when no settlement can be reached, they make a judgment. The values invoked are based on Islamic religion (but not shari'a law as such), and the "customs, traditions of the people, and natural law" which seems to be a kind of secular morality (Boehringer 2013a).

\section{Brazil}

Recently in Brazil I was able to speak with 5 cadres from the League of Poor Peasants (LCP) who attended sessions of the 5th Congress of the International Association of People's Lawyers in Rio, February 2014 (Boehringer 2014b). The LCP is the second largest peasant group engaged in occupations of vacant and unproductive land that is owned by large landholders. It is an off-shoot (in 1994) from the first and largest association of landless occupiers in recent times, the Landless Peasants Movement (MST). The cadres of the LCP informed me that there has been resistance in the form of re-taking land by indigenous and peasant peoples since the beginning of Portuguese colonization about 500 years ago.

In Brazil, LCP communities exist mostly in the poorest areas of the country. Although numbers were not given, I would estimate there are hundreds of thousands of members. (I was told by the five cadres I interviewed that up to 20,000 activists attend periodic LCP 
congresses). They are regulated in general according to the 39 page Constitution of the LCP, Nosso Caminho "our path". The primary principle is one of collective solidarity. Their approach, amongst others, inspired by Maoism, seems quite flexible and pragmatic: living and housing is based on families and there is still considerable family production, although collective production is the ultimate goal.

Although the post military dictatorship Constitution adopted in 1988 allowed for unproductive land to be expropriated and given to the peasants, in recent years the Workers' Party dominated governments of former President Lula da Silva, and now President Dilma Rousseff, ceased to do so and has adopted policies very friendly to agribusiness. It might be thought that this is a factor contributing to the impunity which has existed in the cases of the murders of 448 environmental activists, by far the worst record in the world (Global Witness 2014). This is part of the background to the occupations today. Also important in understanding such occupations is the nature of land-holding in the country. A huge amount of land is owned by a small elite of landlords. Much of their land remains empty and unproductive in a country where there are substantial rates of poverty, homelessness and hunger.

When a group from the LCP takes possession of the vacant land of the landlord, they organize themselves into a self-governing community. They do this with assistance from other LCP communities already established in the region. They have three primary tasks: 1) to establish a people's school to develop the reading and writing capacity of the people (children are still sent to state schools at this stage); 2) to organize production, collectively where appropriate; 3) to establish groups to maintain security against the paramilitary forces of the landlord, or the state. Another of their tasks is to deal with disputes and behavior which is deemed by the community to be unacceptable. They do not use the courts, nor the law of the state. The only significant exception to this is the use of people's lawyers brought to court to defend them as a result of the occupation and/or self-defense activity in resistance to the violence raised against them by the landlords or the state.

The LCP occupiers have developed their own system of dealing with alleged "infractions" (which I was told are not frequent nor are they often very serious). The emphasis is upon resolving disputes informally through discussion so that the parties are reconciled and the community is able to move on together. Where there is behavior that harms others, the idea is to reconcile the parties involved, but in addition to try to get the "perpetrator" to understand their responsibility to others and thereby to cease acting in a destructive manner.

In some of these cases a People's Assembly-open to all- will deal with the matter directly. Normally though, there are prior discussions with the parties involved in order to clarify the issues and seek to prepare the confrontation in a reasonable manner when it is brought to 
the Assembly. At the People's Assembly the accused have the right to speak, or have another speak, in their defense. If the accused are dissatisfied with the decision of the Assembly, an appeal is allowed, first at the local level to an elected political coordinator (a kind of supervisor of community activities) then, if necessary, to a regional coordinator for further review. If the latter upholds the appeal, the matter is returned to the Assembly for discussion and resolution.

The guiding principles and values of their system were explained to me by the cadres as being based in "the national and international experience of the people" (cited were Peru, Turkey, India, Nepal and the Philippines). In particular, inspiration has been drawn from Mao's ideas on handling contradictions amongst the people. The cadres said that religious values were important in dealing with specific issues, and that most of the peasants in the LCP came out of the protestant tradition in Brazil, which was rather surprising given the strength of the colonial heritage of Roman Catholicism. It did, however, point to the marginalized status that these landless peasants have in the class based Brazilian society.

\section{Conclusion}

I mention these different examples of developments in seeking justice and social justice because it is important that we who are imprisoned within a mindset of a state based rule of law learn from the experiences of these courageous and innovative people. Lessonstactical, strategic, organizational, jurisprudential and philosophical, historical-are out there in the experience of thousands of lawyers for the people and amongst the people who are resisting in structures and processes they have created for themselves. Scattered over the globe and mostly unpublished, even undocumented, such lessons must be recovered and considered. This is true especially for people's lawyers and other progressives involved in any way in struggles for justice. It is important for us to analyze the world in which we operate, the social forces which are arrayed for and against social justice, in order to see more clearly how to engage in the struggles we face inside and outside the law, both in the short and long terms.

Lawyers, and probably people's lawyers at the beginning of their careers, have an understandable tendency to be somewhat narrowly focused on the legal process, in particular the courts and other institutions of the state. Largely this is because of the nature of their legal education, the ideology and mystique of law, professional socialization, requirements of the practice of law, client expectations, etc. Today progressive people, including people's lawyers, need to be aware of the many different forms of people resistance, and be ready to 
apply their skills and knowledge in aid of such resistances, some of which will be outside the mainstream of legal struggle.

It is also important that people's lawyers and other progressive people consider the alternative modes of resistance lawyering and people's struggles for justice that are developing across the world. Such consideration includes such matters as the importance of the ideology and organization of the people's law work which, as in the Istanbul People's Law Office collective, challenges both the hegemony of capitalism and the associated bourgeois understandings of the rule of law and its implementation by lawyers and state agencies. Further, the lawyers of the Istanbul lawyer's collective have rejected the bourgeois individualistic concepts of professional organization of law practice. I mention this not because it is a model which would suit all countries at this time, it surely wouldn't, but because it represents one way of integrating one's personal commitments, professional capacity and political-legal practice. It is important to document such an achievement.

Comprehensive social justice will require a revolutionary change from the social formation of capitalism to a more humane system of social, political and economic relations. The developments I have discussed above must be seen as a small, sectorial part of a general transitional process which is just beginning. There is no roadmap. We will get to the future through the experience of the past. The state corporate nexus will stand in our way, determined to conserve the system of repression and exploitation which emerged and evolved over centuries. When the revolutionary process sweeps away the existing unjust system, we will be better prepared to enter that unknown social formation if we have learned from the experiments which are being carried out in places like Brazil, Chiapis, North Kurdistan and the Philippines (Buchanan and Zumbansen 2014).

\section{References}

Bakan J (2004) The corporation: The pathological pursuit of profit and power. London: Constable.

Boehringer G (2009) People's lawyering: The Filipino model-history and practice. In The International Association of Democratic Lawyers Conference, Hanoi, Vietnam.

Boehringer G (2011) Imperialism: The Necessity of state and corporate violence and terror-domestic and foreign. In Human Rights Conferenc, Manila, Philippines.

Boehringer G (2013a) Notes of an interview with Kurds re alternative justice system in North Kurdistan (eastern Turkey).

Boehringer G (2013b) A new strategy in the struggle for human rights and social justice- local people's tribunals. In The International Conference on Human Rights and Peace in the Philippines, Manila, Philippines. 
Boehringer G (2014b) Notes of an interview on governance and justice with cadres of the League of Poor Peasants (LCP) of Brazil who have occupied unproductive land of landlords.

Boehringer G (2014c) Bringing the State and Corporation to Justice: democratic justice and the potential of Local People's Tribunals. In International Association of Democratic, $18^{\text {th }}$ Congress, Brussels, Belgium.

Boehringer G (2014d) Local people's tribunals: A neglected institution for trade union recruitment, campaigns and social movement solidarity. $5^{\text {th }}$ Labour Start Solidarity Conference, Berlin, Germany.

Buchanan R, Zumbansen P (Eds) (2014) Law in transition: Human rights, development and transitional justice. Oxford: Hart Publishing.

Byrnes A (2012) Claiming international law for the people: the persistence and role of civil society tribunals in the modern world. In A Byrnes, G Simm Universitat Zurich Rechtswissenschaftliche Fackultat,. People's Tribunals, International law and the Use of Force, UNSW Law J. 36(2): 711-744.

Colmenares N (2013) A Strategy for people's lawyers: Toward a legal counteroffensive. In International Conference on Human Rights and Peace in the Philippines. Manila, Philippines.

Democratic Society Party (Turkey) (2008) Autonomy Project: Democratic Society Party's Project of Democratic Solution to the Kurdish Question (in Turkish, Kurdish and English), Ankara, Turkey. (The party was declared illegal and was succeeded by the Peace and Democracy Party-BDP).

Esteva G, Prakash M (1998) Grassroots postmodernism: Remaking the soil of cultures. London: Zed Books.

Garth B, Sarat A (Eds) (1998) How Does Law Matter? Evanston, Illinois: Northwestern University Press.

Ginger A (1972) The relevant lawyers: Conversations Out of court on their clients, practice, politics and life style. New York: Simon and Schuster.

Global Witness (2014) Deadly environment. London. Retrieved from: http://bit.ly/1hEIueQ. [Accessed 1 January 2015].

GRAIN (2012) The Great Food Robbery: How corporations control food, grab land and destroy the climate. Barcelona: GRAIN, and Nairobi, CapeTown, Dakar and Oxford: Pambazuka Press.

Hayden T (Ed.) (2002) The Zapatista Reader. New York: Thunder's Mouth Press/ Nation Books.

Klinghoffer A, Klinghoffer J (2002) International citizens' tribunals: Mobilizing public opinion to advance human rights. London: Palgrave MacMillan.

Kowarsch (2013) A struggle for self-determination and national liberation in Kurdistan. [unpublished paper] CENI-Kurdish Women Peace Office, Dusseldorf, Germany.

Lechner F, Boli J (Eds) (2012) The Globalization Reader $4^{\text {th }}$ ed. Chichester: WileyBlackwell.

Nayar R (2001) A people's tribunal against the crime of silence?-The politics of judgement and an agenda for people's law. Social Justice \& Global Development Journal (LGD) 2001(2). Retrieved from: http://bit.ly/1YeD1zn. [Accessed 31 January 2014].

Nayar R (2003) Thinking the 'Impossible': People's Law" Law. Social Justice \& Global Development Journal (LGD) 2003 (1). Retrieved from: http://bit.ly/1Msf57Q. [Accessed 13 January 2014]. 
Nayar R (2006) Taking Empire Seriously: Empire's Law, People's Law and the World Tribunal on Iraq. In A Bartholomew (Ed.) Empire's Law: The American Imperial Project and the 'War to Remake the World. London: Pluto Press: 313-339.

Nayar R (2007) People's law: Decolonising Legal Imagination. Law, Social Justice \& Global Development Journal (LGD), (2007) (1), Retrieved from: http://bit.ly/1KRHWlX. [Accessed 13 January 2014].

OECD Report (2014) Society at a Glance 2014. Retrieved from: http://bit.ly/liyzaI5. [Accessed 1 January 2015].

Oxfam Report (2014) Working for the few. Political capture and economic inequality. Retrieved from: http://bit.ly/1JX9AfS. [Accessed 1 January, 2015].

Ross R, Trachte K (1990) Global capitalism: the new leviathan. New York: State University of New York Press.

Sands P (2006) Lawless World: Making and Breaking Global Rules. London: Penguin.

Sarat A, Scheingold S (Eds) (2005) The Worlds Cause Lawyers Make: structure and agency in legal practice, Stanford Law and Politics. California: Stanford.

Tubbs M (2013) The Dictatorship of capital: the new corporate world order. Queensland: Boolarong Press .

Womack J (Ed.) (1999) Rebellion in Chiapis: An Historical Reader. New York: New Press.

WSWS (World Socialist Website) (2014) The OECD's "Society at a Glance report: a portrait of a failed system". Retrieved from: http://bit.ly/1Kg7d3A. [Accessed 1 January 2015]. 
